\title{
Correction: Ubiquitin B: an essential mediator of trichostatin A-induced tumor-selective killing in human cancer cells
}

P. Wu, Y. Tian, G. Chen, B. Wang, L. Gui, L. Xi, X. Ma, Y. Fang, T. Zhu, D. Wang, L. Meng, G. Xu, S. Wang, D. Ma and J. Zhou

(c) The Author(s), under exclusive licence to ADMC Associazione Differenziamento e Morte Cellulare 2021

Cell Death \& Differentiation (2022) 29:1299; https://doi.org/10.1038/s41418-021-00829-5

Correction to: Cell Death and Differentiation https://doi.org/ $10.1038 /$ cdd. 2009.142

The original version of this article unfortunately contained a mistake. In figure $2 a$, the authors mistakenly used the same image in the different cell lines HeLa and MCF-7. The corrected figure can be found below. The authors apologize for the error.
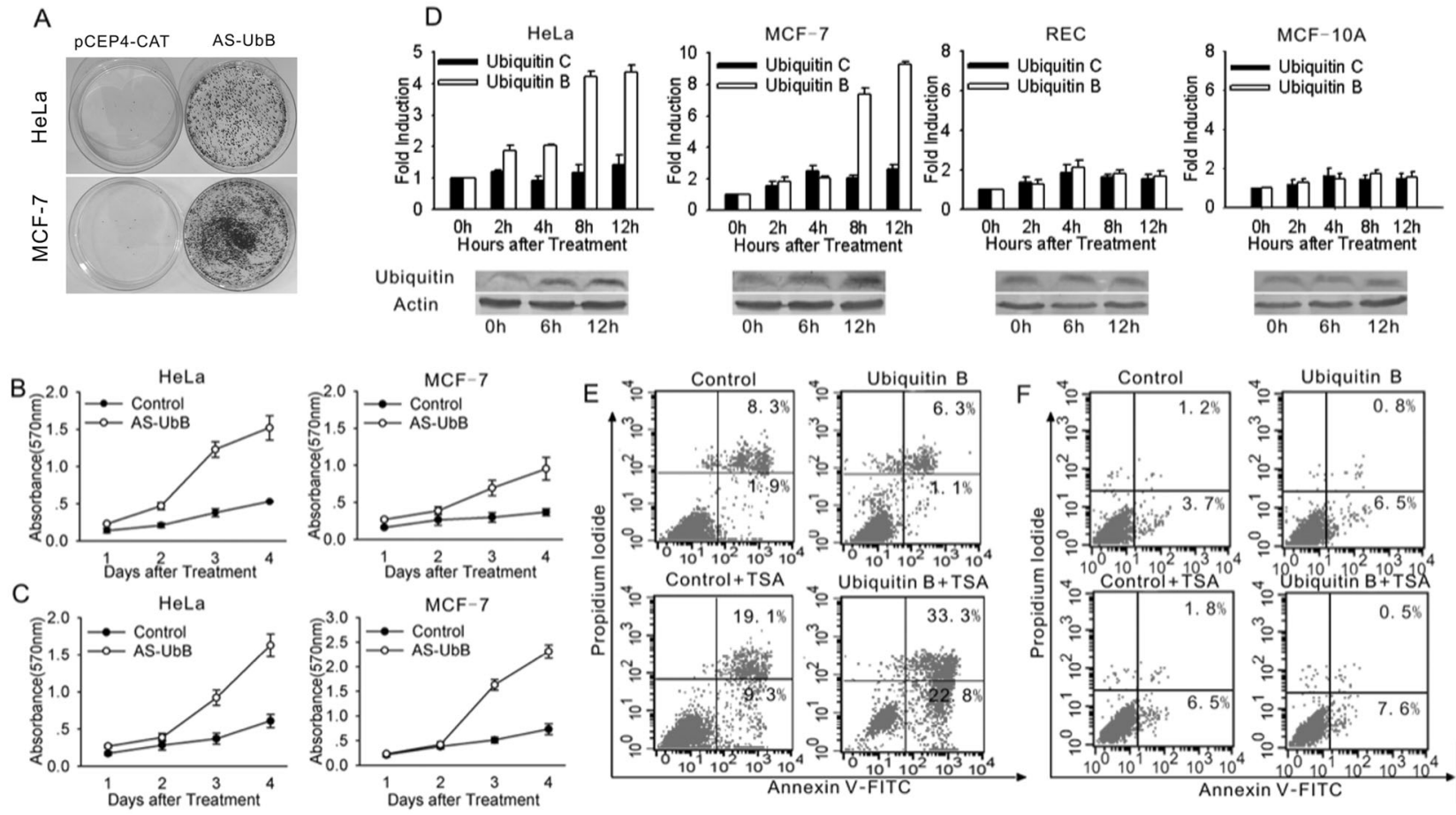